\title{
Juha Vartola in memoriam
}

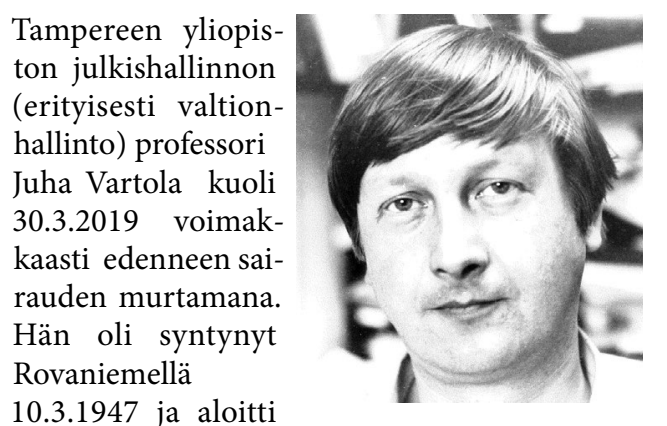

opinnot Tampereen yliopistossa 1967, jolloin pari vuotta aiemmin perustettuun julkishallinnon professuuriin nimitettiin Kauko Sipponen.

Vuodesta 1971 lähtien Vartola toimi Tampereen yliopistossa aina eläkkeelle siirtymiseensä asti vuoden 2013 lopussa. Kysyntä hallintotieteellisten aineiden opetuksesta oli 70- ja 80-luvuilla valtava, koska julkinen hallinto kasvoi kovaa vauhtia sille osoitettujen uusien tehtävien myötä. Niinpä Vartolakin joutui opetustehtäviin varsin nopeasti jo kauan ennen nimitystään oppiaineensa professoriksi 1980. Opetusurallaan hän koulutti julkisen hallinnon asiantuntijatehtäviin tuhansia henkilöitä, joista monet tulivat toimimaan valtionhallinnon keskeisissä kehittämis-, asiantuntija- ja johtotehtävissä.

Juha Vartola arvosti hallinnon tutkimuksen klassikoita. Hänen mukaansa ne nostivat tärkeitä kysymyksiä, joita on syytä pohtia, eikä maailmakaan muutu kaikessa suhteessa niin paljon kuin luullaan. Vartola korosti syvällistä ymmärrystä asioista, tervettä kriittisyyttä ja nöyryyttä. Samoin hän painotti laaja-alaisuutta ja yleissivistystä niin tieteen, yhteiskunnan kuin kulttuurin ymmärtämisessä.

Jälkeenpäin katsottuna ajanjakso 1960-luvun alusta1980-luvun loppuun näyttäytyy ns. hyvinvointivaltion kautena, jolloin valtio otti vahvasti vastuuta kansalaisten hyvinvoinnista ja taloudellisesta kehityksestä. Suomen hallintoideologiaa leimasi eduskunnan lainsäädäntötukeen nojaava valtiolähtöinen suunnittelu- ja kehitysoptimismi. Kuten tiedetään, valtio osoitti merkittävän osan omaksumistaan tehtävistä kunnille.
Tämä vauhditti itse valtion ja muiden julkisten organisaatioiden (kuntien ja ns. väliportaanhallinnon) toimintojen ja virkamieskunnan kasvua.

Juha Vartola oli koko tuon ajanjakson tärkeässä roolissa mm. ministeriöiden ja keskusvirastojen sekä virkamieskunnan kehityskulkujen sekä ennen kaikkea valtiobyrokratian rakenteen ja roolin kehityksen ulkopuolisena empiirisenä ja teoreettisena tarkkailijana. Hän toimi luonnollisesti myös kehittämistoiminnassa käytettynä asiantuntijana. Valtion uusiin tehtäviin liittyvän väljän normiohjauksen sekä yhteiskuntatieteellisen ajattelun merkityksen kasvun mukanaan tuoma hallinnon asiantuntijavaltaistuminen, hallinnon eri haarojen diversifioituminen sekä yhteiskunnan suhteellinen byrokratisoituminen ovat esimerkkejä Vartolan tekemistä tieteellisistä johtopäätöksistä.

Juha Vartola oli myös ensimmäisiä tutkijoita Suomessa, jotka kirjoittivat siitä, miten julkisen hallinnon tutkimusta tulisi tehdä. Varsin käytetty oli hänen yliopiston sarjassa 1970-luvulla julkaisemansa metodiopas "Johdatusta hallinnon tutkimukseen”. Hän oli myös käynnistämässä tiivistä yhteistyötä käytännön toimijoiden ja tutkijoiden välille. Juha Vartola oli johtamassa jo 1980-luvun taitteessa ministeriötutkimusta, jonka tilasi silloinen valtiovarainministeriön järjestelyosasto.

Väitöskirjassaan vuonna 1979 Vartola käsitteli valtionhallinnon rakenteellista muutosta erityisesti Max Weberin yhteiskunta- ja byrokratiateorian kautta. Weberin ajatteluun pohjautuvat kehittelyt ja sovellukset kulloinkin muuttuneessa yhteiskunnallisessa tilanteessa säilyivätkin Vartolan tutkimuksen ja opetuksen ytimessä koko uran ajan.

Rakenteellisella muutoksella Vartola tarkoitti weberiläisittäin muutoksia koko poliittis-hallinnollisessa systeemissä (jonka ytimessä on valtiobyrokratia) ja sen suhteissa muihin yhteiskunnallisiin systeemeihin, ei vain muutoksia julkisen hallinnon organisaatiorakenteessa. Tähän käsitemäärittelyyn kiteytyvällä Weberin "oikealla" makrotasoisella tulkinnalla Vartola 
poikkesi selkeästi 1950-luvulla anglo-saksisessa organisaatiotutkimuksessa nousseesta ja kansainväliseen hallintotieteelliseen keskusteluun sittemmin levinneestä Weberin mikrotasoisesta tulkinnasta (mm. ns. Aston-ryhmä), joka käytti etenkin Weberin byrokratiateoriaa vain organisaatio- ja johtamisteoriana. Juha Vartolan väitöskirja loi myös suomalaiselle hallinnon tutkimukselle vahvan perinteen, jossa se integroitui yhteiskunnallisen kehityksen ymmärtämiseen ja kriittiseen tutkimukseen.

Byrokratiateorian ja yhteiskunnallisen näkökulman esillä pitämiset olivat Vartolan keskeisiä sanomia myös kansainvälisissä konferensseissa (EGPA, IIAS ja IASIA), joissa hän esitti papereita ja käytti puheenvuoroja. Mainitusta syystä hän suhtautui myöhemmin varsin kriittisesti uuden julkisen hallinnon oppeihin ja julkisen hallinnon managerialistiseen lähestymistapaan. Vartola oli tutkijanotteeltaan myös sosiologi, ja hän piti mikrolähestymistapaa liian yksipuolisena julkisen hallinnon tieteelliseen erittelyyn. Hän piti yllä julkishallinnon tutkimuksellisen paradigman yhteyksiä valtioteoriaan, mitä voidaan pitää suomalaisessa hallinnontutkimuksessa tärkeänä linkkinä edelleen.

Monille opiskelijasukupolville weberiläinen analyysi on ollut reitti ensin julkisen hallinnon kasvavan ja aktiiviseksi muuttuvan roolin, sitten uuden julkisen johtamisen (New Public Management) sekä vihdoin yhteiskunnan poliittis-hallinnollis-taloudellisen hallinnan (Governance) käsitteistämiseen ja ymmärtämiseen. Weberin ydinteemat - hallinnon legitimiteetistä eli oikeutuksesta huolehtiminen sekä hallinnon kulloisetkin tehokkuus- ja rationaalisuushaasteet - loivat Vartolan akateemisesta profiilista makropainotteisen ja verrattain teoreettisen. Mainittuja teemoja hän kokosi mm. teokseensa Näkökulmia byrokratiaan (2004), ja niitä on kehitelty myös monien kolleegojen toimesta Juha Vartolan juhlakirjassa Felix Byrokratia? (2015).

Teoreettisesti vahvaa valtioteoriasidonnaista makronäkökulmaa tarvitaan yhä $\mathrm{mm}$. valtio- byrokratian roolin ja julkisen/yksityisen toimijuuden erittelyssä. Kansalaisten, alueiden ja eri intressitahojen, jopa valtioiden toiminta saa mitä moninaisimpia ja usein kärjistyviäkin muotoja (esimerkiksi sote-palveluiden organisointi Suomessa, palveluiden ja viranomaistoimintojen ulkoistaminen, EU:n maahanmuuttajakysymys, Brexit, valtioiden puolustuksellinen ja terrorisminvastainen yhteistoiminta, EU:n liittovaltiokehitys, Katalonian itsenäisyysliikehdintä).

Voisimme siis jopa väittää, että Juha Vartolan henkinen perintö kutsuu valtion ja sen byrokratian asemaa problematisoivaa tutkimusta lisää. Hahmottuuhan tyypillisesti weberiläinen kysymys julkisen vallan luonteesta ja virkamieskunnan asemasta nykyään enemmänkin hallintooikeudellisena kuin -tieteellisenä kysymyksenä. Vähälle teoreettiselle huomiolle on toistaiseksi jäänyt myös esimerkiksi klassisen virkamieskäsityksen vähittäinen eroosio työsopimussuhteisuuden lisääntymisen, "pätkävirkamiestyön" yleistymisen ja uraliikkuvuuden dynamisoitumisen myötä. Tällaiset virkamiespätevyyden kysymykset olivat yksi Juha Vartolan tutkimuskohteista.

Juha Vartolan kiinnostus suuntautui myös kehittyvien maiden julkisen hallinnon kehittämiseen. Toimiessaan ulkomaisten tohtoriopiskelijoiden väitöskirjojen ohjaajana ja kehityshankkeiden asiantuntijana hän tuli huomaamaan, että oikeusvaltio ideaalityypin kuvaamine byrokratioineen on monissa maissa vielä kaukainen unelma eikä kehittyneemissäkään maissa itsestäänselvyys. Vartola osallistui aktiivisesti edellä mainittujen kansainvälisten järjestöjen toimintaan ja sitä kauttakin hänen käsityksensä eri maiden hallintokysymyksistä oli laaja.

Hallinnon Tutkimuksen Seuran perustamisessa vuonna 1981 Juha Vartolan henkilökohtainen panos oli merkittävä. Hän toimi myös seuran alkuvaiheessa seuran puheenjohtajana ja Hallinnon Tutkimus-vuosikirjan päätoimittajana.

Klaus af Ursin \& Jari Stenvall 